International Journal of English Literature and Social Sciences
Vol-6, Issue-3; May-Jun, 2021
Journal Home Page Available: https://ijels.com/
Journal DOI: $10.22161 /$ ijels

Peer-Reviewed Journal

\title{
A Comparative Study of Emergency Remote Education Amid COVID-19
}

\section{Liu Zhixuan}

Faculty of English Language and Culture, Guangdong University of Foreign Studies, Guangzhou, China

Received: 31 Mar 2021; Received in revised form: 03 May 2021; Accepted: 22 May 2021; Available online: 13 Jun 2021 (C2021 The Author(s). Published by Infogain Publication. This is an open access article under the CC BY license (https://creativecommons.org/licenses/by/4.0/).

\begin{abstract}
The outbreak of the new coronavirus pneumonia (COVID-19) severely threatened people's health and safety for a long period. It has caused a serious impact on people's work, life, and learning. Most governments around the world have temporarily closed educational institutions in an attempt to contain the spread of COVID-19. These nationwide closures are impacting over $91 \%$ of the world's student population (UNESCO, 2020). As a response to the interruption of education due to the crisis, this study compares emergency remote learning cases in three countries, namely India, China, and the United States, narrating the overall view, reflections, and lessons learnt in the education field. The findings show that there are some common challenges that all of the three countries are facing, like ensuring every student having access to remote education, unprepared teachers, increased burden of parents as well as students' lack of self-discipline when isolated at home. With challenges, come opportunities such as education transformation from a traditional system to a new era as well as improvement of digital literacy. Finally, suggestions on improving remote education from the viewpoint of policymakers, teachers, and students are given to escalate the level of remote education during the pandemic, so as to promote the reform of information-based education.
\end{abstract}

Keywords - emergency remote education, online education, language teaching, Covid-19.

\section{INTRODUCTION}

During the first half of 2020, the outbreak of the COVID-19 pandemic had a huge global impact. People's physical health all over the world was to some extent threatened and affected, resulting in numerous deaths. Furthermore, all aspects of human coexistence came under great pressure, such as economic activities, psychological well-being, political relations, and international education. A key challenge for higher education in response to the pandemic is to shift teaching and learning from face-toface to online delivery. At some institutions, faculty were given just a short time to prepare to move all instruction remotely. This sudden pedagogical change is, however, different from actual planned online teaching (Hodges, Moore, Lockee, Trust \& Bond, 2020). The rapid, unexpected and 'forced' transition from off-line teaching to remote teaching has entailed a number of challenges and constraints but also opportunities and possibilities that need to be examined. It would be a great benefit to reflect on what we can learn from those who are pioneering new approaches and technologies in online education. This article will first provide a review of the literature on online education and its difference from the current emergency remote education and then compare different countries' policies and patterns in implementing remote education. The implications of this study for the development of future online teaching and learning practices will also be discussed.

\section{LITERATURE REVIEW}

\subsection{Online education}

Online education is defined by Khan (1997) as the delivery of instruction to a remote audience using the web as an intermediary. Most authors such as Benson (2002: 443) define online education in terms of access to learning 
experiences but also on the potential for flexibility and participant interaction. Distance education is defined as 'any educational process in which all or most of the teaching is conducted by someone removed in space and time from the learner, with the effect that all or most of the communication between teachers and learners is through an artificial medium, either electronic or print' (UNESCO, 2002: 22). Nevertheless, it 'is not simply a geographical separation of learners and teachers, but, more importantly, is a pedagogical concept' (Moore, 1997: 22).

There are different forms of online education, such as using one or a mix of the following instruction methods: 100\% Online Education, Blended Education, Individual Online Courses and Massive Open Online Courses (MOOCs). These courses and programs provide students with flexible learning opportunities. Online education can be adaptive; allows for enhanced, individualized, and authentic materials; can take advantage of communicative tasks and multilingual communities; can foster and take advantage of autonomous learning and learner corpora (Goertler, 2019: 51). It involves careful course design and planning in a systematic model. The design process and careful consideration of different design decisions influence the quality of the instruction.

Online education has been studied for decades. Studies have consistently shown no significant differences and even slight advantage for the online/blended courses in comparison studies (Goertler \& Gacs, 2018; Chapelle, 2010; Means, Toyama, Murphy, Bakia \& Jones, 2009).

According to data provided by the National Center for Education Statistics (National Center for Education Statistics, 2019a), in fall 2018, about 5.7 million undergraduate students $(35 \%$ of total undergraduate enrollment) in the US were taking at least one distance education course.

In 2020, due to the outbreak of COVID-19, almost all the universities across the world have adopted online learning. For example, the Chinese Ministry of Education announced postponing the opening of all schools and universities in the spring which is named as the requirement of "no suspension of classes".

\subsection{Emergency Remote education}

The educational practices during the pandemic have different terms in different countries, such as distance education, online education, homeschooling, etc. But these couldn't perfectly describe what is being practiced during the education interruption, which could be better named as emergency remote education. In contrast to online education which is well planned from the beginning and designed to be online, emergency remote education as a branch of online learning is an alternative temporary shift mode of delivery due to crisis (Hodges et al, 2020). In other words, it is a crisis-prompted online teaching mode. The main of it is to provide temporary access to instruction in a manner that is quick to set up and is available during a crisis. Many cases are responding to university closures in a time of crisis by using mobile learning, radios, blended learning and so on. In a study on education's role in fragility and emergencies, radio education and DVDs were also used to maintain and expand educational access and were aimed at promoting education for girls in Afghanistan, where education was disrupted by conflict and violence (Lynn Davies \& Denise Bentrovato, 2011).

In general, a complete online course requires an elaborate lesson plan design, teaching materials such as audios and videos, as well as technology support teams. However, due to the sudden emergence of the COVID-19, most faculty members are conducting emergency remote education (shorten as remote education below), facing the challenges of lacking online teaching experience, early preparation, or suitable teaching approaches. Therefore, this research would like to compare Indian, American and Chinese remote learning cases which have achieved a relatively satisfactory result across the world (Bozkurt et al, 2020). It aims to find out how different countries deal with emergency remote learning as well as what are the challenges and opportunities of remote education and what practical lessons can be learned for education's recovery from the pandemic.

\section{OVERVIEW OF REMOTE EDUCATION IN INDIA, CHINA AND THE UNITED STATES}

\subsection{India}

COVID-19 has impacted immensely the education sector of India. Initially, education was suspended but the teachers and staff were required to continue. Later on, when the infection started spreading faster and faster, the University Grants Commission on March 21, 2020, said that faculty members and non-teaching staff were permitted to work from home till 31st March. Many institutes in India have successfully adopted online learning before this crisis (Sharma, 2001). But not all teachers and students are good at it or at least not all of them were ready for this sudden transition. The days during the pandemic were the boom time for various live video conferencing apps like Zoom, Google Meet, Facebook, YouTube, and Skype, etc. Instant chat messaging such as WhatsApp had already been in use in Indian educational institutions. Teachers and students were advised to make use of Information and Communications Technology (ICT) initiatives offered through digital platforms of the Ministry of Human Resource 
Development, University Grants Commission and Consortium of Educational Communication. Teachers who were skilled at ICT quickly switched to remote teaching tools, whereas the majority of other teachers found it challenging to use digital platforms. Universities conducted training programs for faculty using online resources and the creation of teaching materials.

The lockdown has compelled many educational institutions to cancel their classes, examinations, internships, and to choose the online modes. Complaints and challenges were brought to the notice of the general public. The prominent one among them is that many students don't have computers or laptops at home. Besides, students were wrongly considered to have a lot of free time at home. They have to do household chores and some even suffer domestic abuse and violence. Further, teachers and students were forced to go online, however few knew how to teach and learn online as being in the state of unpreparedness. There was inadequate or little discussion on pedagogical approaches. Although the outbreak of this pandemic has caused many negative impacts on education, educational institutions in India have embraced the challenge of the transformation from a traditional system to a new era and trying their best to offer support services to students and teachers. Educational institutions moved towards a blended mode of learning encouraging teachers and students to learn and use digital technology, which will result in increasing digital literacy (Pravat Kumar Jena, 2020:12).

\subsection{China}

Since the beginning of the 21 st century, Chinese universities have launched online education reforms to form an open education network based on the information and network technologies. With the rapid development of MOOCs, the number of these online courses offered by Chinese universities has exceeded 500, and nearly 3 million people have participated in these courses (Shang \& Cao, 2017). When the epidemic occurred during the winter vacation in 2020, the Ministry of Education was quick to take a proactive approach by requiring all schools to make use of online platforms to ensure no disruption of learning and teaching when the spring semester began while the schools remained closed. At once, almost all schools and universities all over the country plunged into the preparation of emergency remote education. In a short period, millions of faculty members started to teach in front of a computer screen and students have to stay at home and take courses through the Internet. K12 (a short form for the grades from kindergarten to the 12th grade) schools usually followed the offline routine schedule. Emergency remote education is Internet-based and in mobile mode, or sometimes TV-based, which is used for
K12 students in remote areas or from lower socioeconomic backgrounds. According to a survey collecting user experience data on online education platforms in China during the pandemic (Chen, Tinggui, et al, 2020), Ding Ding and Tencent Class are the most popular platforms which could guarantee a high-quality learning experience, while other less popular platforms like Chaoxing Learning and MOOC encountered several problems, such as the inability to submit the learning time, lags, and a significant video delay.

Remote teaching proved to be a great challenge for most K12 teachers, especially senior ones, but less difficult for instructors in universities. The reason is that there had been few online elements in K12 classrooms. Besides, K12 teachers may be more sensitive to their students' emotional reactions and take appropriate measures to help them overcome negative emotions because this is part of their job in an offline setting. In contrast, university teachers may be less sensitive in this regard because university students are often taken to be adults having the capability to regulate their mood.

After receiving complaints both from teachers and the general public, the government reiterated that emergency remote education was only part of the response to school closures and immediately took actions to redress the problem, such as recommending the use of already available Open Educational Resources or suggesting leading teachers share their lectures among their peers and some other arrangements to help students go through this difficult situation.

According to Brander (2020), K12 students might find it fun to experience the novelty of online education since they had usually not been allowed to even use their mobile phones at school or home before this pandemic. But when the novelty was gone, they missed offline classrooms. Gradually, there appear all the more issues like digital divide, accessibility and teacher's overload. Students often have problems such as a lack of a good learning attitude, suitable learning materials, or a good study environment when they are at home. As for college students, they have many other things to worry about, such as ambiguous future career goals, no interest in academic research, etc.

\subsection{The United States}

In late February 2020, school officials started discussing the serious disruption in education and preparing for possible school and university closures. After the WHO characterized Covid-19 as a pandemic on March 11, 2020, the U.S. declared a national emergency on March 13, 2020, when most colleges and universities began to switch to remote learning. A few days later, K12 
school districts all over the country also decided to close schools and move to emergency remote education with little advance notice.

At the macro level, the transition to alternative delivery modes has been framed as a move to "online" teaching and learning in higher education and a move to "off-campus" or "remote" teaching and learning in K12 education. Some schools that cannot implement online education well during school closures didn't give up. For example, in Los Angeles, schools partnered with local Public Broadcasting Service stations so that students could receive education through televisions. Students in this area started to watch educational episodes and documentaries that were aligned to state standards (Noonoo, 2020). At the micro-level, practical instructional decisions are left to teachers. The pedagogical approaches which have been put into practice in virtual classes have varied among teachers and instructors. In higher education, professors move their classes online and use synchronous and asynchronous Internet-based educational technologies. Some other instructors still hold classes on scheduled days and times with synchronous online video conferencing tools. Both teachers and students feel it incredibly exhausting in terms of time input and intellectual focus. Other teachers combine asynchronous technologies like narrated slide presentations or video recordings to replace lectures and activities using a range of audio-based educational technologies. In K12 education, teachers are often left to make their own decisions for teaching contents and objectives. Their teaching methods have been various, with some teachers replicating the school day with an hour-by-hour agenda for students at home, while others have daily or weekly homework that students must finish in their spare time.

There are also numerous concerns associated with remote education in the United States. What is frequently mentioned is teachers' lacking preparation and a sense of loss of personal connection with their students. Students are experiencing a lack of connection with their teachers as well as a lack of clarity about how to manage learning in this new format. At the same time, mobile compatibility of websites is often problematic and not all students can afford unlimited data usage. Some parents are finding it difficult to manage and support children's educational requirements. They have little preparation or qualification to do so. A quite number of parents show concerns about the lack of technology devices or Internet access at home, as well as inadequate communication with schools and teachers. It is a fact that not all students own personal devices. They may lack access to technology resources to do even the basic tasks such as receiving information from instructors. What's worse, the school closure also brings a great challenge for the students from low-income families who depend on their schools for meals and parents who rely on schools for child care programs (Binkley, 2020).

\section{REFLECTIONS FROM THE CASES}

\subsection{Lessons Learned from Cases}

There is no doubt that emergency remote education was the best and perhaps the only option to help cope with school closures during the Covid-19 pandemic around the globe. Educational approaches have universally relied most heavily on Internet technologies to mediate learning and communication between schools, teachers, students and families. People must learn and live with technology and will continue to do so in the long run. This pandemic has presented many challenges, barriers and difficulties on education, among which the most prominent and basic one is access to the Internet. This problem is most serious in India, with the other two countries using televisions as an alternative. Numerous advanced educational institutions in India are not equipped with digital facilities right now to cope up with sudden change from traditional education to the online education system. (Pravat Kumar Jena, 2020) Access to education is a fundamental human right. And it is difficult to find hope in this situation unless digital equity is addressed and access is prioritized going forward. Another major difficulty is teachers' lack of preparation and experience in emergency remote teaching. Although India has the previous exploration in online teaching, emergency remote teaching is different from carefully planned online teaching and just a small part of teachers have experience which increased the other teachers' anxiety. Indian government pays more attention to this issue and takes quick actions to address it.

But this unprecedented crisis has also illuminated many benefits, opportunities and possibilities. For teachers as well as students who may not be familiar with technology, this forced shift has required them to try new educational strategies and learn new ways of studying online. For those who are already experienced with technology, it also presents the possibility for introspection about their usual practices, which might bring discoveries. Educators and learners are getting opportunities to interact with peers around the world. Learners are willing to adapt to an international community. Take the remote class style for an example, different countries have their own features. One point is common that many educators are using the Internet now to do the same style of teaching with similar learning activities that they did before schools and universities were closed. And in their attempt to replicate the traditional classroom experience, different teaching strategies reflect their countries' educational values. 
Chinese teachers value lecture and objective assessment more, so they usually deliver lectures and conduct exams or homework remotely through technology. American teachers focus more on inquiry-based learning and studentcentered class; thus, they implement information sharing and discussion activities online. Indian teachers encourage project-based learning and design opportunities for students to demonstrate their learning remotely. The above three teaching styles are not definite. Teachers across the world can learn from other countries' effective experiences. Teaching methods may change or combine two or more styles according to teaching contents, students' levels or characteristics and various cultural backgrounds.

\subsection{Suggestions}

In addition to dealing with the present problems, policymakers and educational leaders must look forward and better prepare for what lies ahead. The above lessons provide a valuable opportunity to consider what has been done well and what can and must be done differently in education in the future.

For policymakers, develop a vision for the future and a strategic plan to support more effective and robust online education initiatives at every level. Meanwhile, any response strategy needs to balance influence from different factors. Otherwise, emergency remote education is likely to deepen social inequality rather than bridge the gap (Olcott, 2020). Hence there is a great need to provide alternative options to cater to learners who are disadvantaged due to poor accessibility or inadequate infrastructure (Bates, 2020).

For teachers, learn to adapt and use open educational resources appropriately rather than spend time producing poor-quality resources of one's own. Teachers and faculty members need to continuously improve technical skills and develop effective pedagogical strategies to provide high-quality remote education. In addition, peer collaboration and support using social media are strongly recommended as most schools and universities suffer from a lack of resources. Finally, reflecting on successes and failures as well as integrating lessons learned into routine work after the crisis is also needed.

For students, they should become self-directed learners as the Internet offers great learning opportunities. Besides, learners should take the initiative to handle their technical limitations and they should also learn how they can integrate the technological advancements into their career communication. Students could also share feelings or experiences frankly with peers or teachers if cannot overcome negative emotions.

\section{REFERENCES}

[1] Bates, T. (2020). Crashing into online learning: a report from five continents - and some conclusions. https://www.tonybates.ca/2020/04/26/crashing-into-onlinelearning-a-report-from-five-continents-and-someconclusions/.

[2] Benson, Angela D. (2002). "Using online learning to meet workforce demand: A case study of stakeholder influence." Quarterly review of distance education, 3(4), 443-52.

[3] Binkley, C. (2020). How U.S. schools are planning for possible spread of coronavirus. Time. https://time. com/5792377/us-schools-coronavirus-plans/.

[4] Bozkurt, Aras, et al. (2020). "A global outlook to the interruption of education due to COVID-19 pandemic: Navigating in a time of uncertainty and crisis." Asian Journal of Distance Education, 15(1), 1-126.

[5] 5.Brander, K. (2020). "The digital irony of the corona virus crisis-opinion." https://www.jpost.com/opinion/the digital irony of the coronavirus crisis opinion 622048 .

[6] Chapelle, Carol. (2010). "The spread of computer-assisted language learning." Language Teaching, 43(01), 66.

[7] Chen, Tinggui et al. (2020). "Analysis of User Satisfaction with Online Education Platforms in China During the COVID-19 Pandemic." Healthcare, 8(3), 200.

[8] Goertler, S. (2019). "Normalizing online learning: Adapting to a changing world of language teaching." From theory and research to new directions in language teaching, 51-92.

[9] Goertler, Senta, and Adam Gacs. (2018). "Assessment in online German: Assessment methods and results." Die Unterrichtspraxis/Teaching German, 51(2), 156-174.

[10] Hodges, C., Moore, S., Lockee, B., Trust, T., \& Bond, A. (2020). The difference between emergency remote teaching and online learning. Educause Review. https://er.educause.edu/articles/2020/3/the-differencebetween-emergency-remote-teaching- and-online-learning.

[11] Khan, B.(1997). Web-based training. Englewood Cliffs. NJ: Educational Technology Publications.

[12] Lynn Davies and Denise Bentrovato, (2011). "Understanding Education's Role in Fragility; Synthesis of Four Situational Analyses of Education and Fragility: Afghanistan, Bosnia and Herzegovina, Cambodia, Liberia," International Institute for Educational Planning.

[13] Means, Barbara, et al. (2009)."Evaluation of evidencebased practices in online learning: A meta-analysis and review of online learning studies." Us Department of Education.

[14] Moore, M. (1997). Theory of transactional distance. In Keegan, D. (Ed.), Theoretical Principles of Distance Education (pp. 22-38). Routledge.

[15] National Center for Education Statistics. (2019a). "Number and percentage of students enrolled in degree-granting postsecondary institutions, by distance education participation, location of student, level of enrollment, and control and level of institution: Fall 2017 and fall 2018". https://nces.

ed.gov/programs/digest/d19/tables/dt19_311.15.asp. 
[16] Noonoo, S. (2020). "Here's what schools can do for the mil- lions of students without internet access. " EdSurge. https://www.edsurge.com/news/2020-03-20-here-s-whatschools-can-do-for-the-millions-of-students-withoutinternet- access.

[17] Olcott Jr, D. (2020). "The leadership imperative: Back to the future after the Covid-10 pandemic." Published by the International Council for Open and Distance Education. https://www. icde. org/icde-blog.

[18] Pravat Kumar Jena. (2020)."Impact of pandemic COVID19 on education in India." International Journal of Current Research, 12.

[19] Shang, J., and P. Cao. (2017). "Internet plus and the reform of higher education: A preliminary study on the development strategy of higher education informatization in China." Peking University Education Review, 1, 173182.

[20] Sharma, R. C. E-Learning in India. In Howard, C., Boettcher, J. V., Justice, L., Schenk, K., (2005). Rogers, P. L., \& Berg, G. (Eds) Encyclopedia of Distance Learning (pp. $772-778$ ). Idea Pub.

[21] Sharma, Ramesh. (2001). "Online Delivery of Programmes: A case study of IGNOU." The International Review of Research In Open And Distributed Learning, 1(2).

[22] UNESCO. (2020). "COVID-19 Educational Disruption and Response." https://en.unesco.org/covid19 /educationresponse.

[23] UNESCO. (2002). "Open and Distance Learning: trends, policy and strategy consideration." UNESCO. 